\title{
HEMATOLOGICAL PARAMETERS AND BODY COMPOSITION OF SOCCER PLAYERS
}

\author{
PARÂMETROS HEMATOLÓGICOS E COMPOSIÇÃO CORPORAL DE ATLETAS DE FUTEBOL
}

Allana Kelly Bussollaro

(Nutritionist)

Barbara Nara de Freitas ${ }^{1}$

(Nutritionist)

Raíssa Maria Fadel

(Nutritionist)

Gabriela Siqueira Lara

(Nutritionist)

Priscila Dabaghi Barbosa ${ }^{1}$ (Nutritionist)

Thais Regina Mezzomo'

(Nutritionist)

1. Universidade Positivo, Curso de Nutrição, Curitiba, PR, Brazil.

\section{Correspondence:}

Thais Regina Mezzomo Rua Pedro Viriato Parigot de Souza, 5300, Campo Comprido, Curitiba, PR, Brazil. 81280-330. thaismezzomo@yahoo.com.br

\begin{abstract}
Introduction: Soccer players may experience hematological changes that could be detrimental to their health status. In addition, inadequate body composition may impair performance. Objective: To assess body composition and hematological changes over a year in soccer players. Methods: A retrospective observational study was conducted. Age, weight, height, body composition, blood count, serum iron, serum ferritin, serum transferrin and total iron binding capacity data were collected from the athletes' medical records in the months of January, May and August of 2015 and January of 2016. Body mass index was also calculated. For the statistical analyses, the Anova and post-hoc Tukey's post-hoc tests were used for the quantitative variables and the Chi-square test for the qualitative variables. The significance level adopted was $p<0.05$. Results: Data were evaluated for 51 athletes with a mean age of $23.53 \pm 3.11$ years, $77.10 \pm 6.56 \mathrm{~kg}, 1.80 \pm 0.07$ and $15.6 \pm 2.89 \%$ body fat (BF). We observed significant $(p<0.05)$ changes in mean corpuscular volume, mean corpuscular hemoglobin, mean corpuscular hemoglobin concentration, cell size and eosinophils during the period evaluated. Among the athletes, 21.6\% had decreased hematocrit levels and 3.9\% had hemoglobin levels below the reference range. A BF\% greater than $16 \%$ was significantly related to serum iron depletion $(p=0.01)$. Conclusion: Small significant hematological changes during the competitive year were observed, but without significant changes in body composition. Level of Evidence III; Study of nonconsecutive patients; without consistently applied reference "gold" standard.
\end{abstract}

Keywords: Soccer; Blood cell count; Iron; Anemia.

\section{RESUMO}

Introdução: Os atletas de futebol podem apresentar alterações hematológicas que podem comprometer o seu estado de saúde. Além disso, a composição corporal inadequada pode prejudicar o respectivo desempenho. Objetivo: Avaliar a composição corporal e as alterações hematológicas ao longo de um ano em atletas de futebol. Métodos: Realizou-se um estudo observacional retrospectivo. Foram coletados dos prontuários dos atletas dados referentes à idade, peso, estatura, composição corporal, hemograma, ferro sérico, ferritina sérica, transferrina sérica e capacidade total de ligação do ferro nos meses de janeiro, maio e agosto de 2015 e janeiro de 2016. O índice de massa corporal também foi calculado. Para as análises estatísticas foram utilizados o teste Anova e o teste post-hoc Tukey para as variáveis quantitativas e o teste de Qui-quadrado para as variáveis qualitativas. O nível de significância adotado foi de $p<0,05$. Resultados: Foram avaliados os dados de 51 atletas, com média de idade de 23,53 $\pm 3,11$ anos, $77,10 \pm 6,56 \mathrm{~kg}$, $1,80 \pm 0,07$ m e 15,6 $\pm 2,89 \%$ de gordura corporal (GC). Observou-se alteração significativa $(p<0,05)$ do volume corpuscular médio, da hemoglobina corpuscular média, da concentração de hemoglobina corpuscular média, do tamanho celular e dos eosinófilos durante o período avaliado. Dentre os atletas, 21,6\% apresentaram hematócrito diminuído e 3,9\% apresentaram hemoglobina abaixo dos valores de referência. A \% de GC maior que 16\% se correlacionou significativamente com a depleção de ferro sérico $(p=0,01)$. Conclusão: Pequenas alterações hematológicas significativas durante o ano de competição esportiva foram observadas, mas sem alterações significativas sobre a composição corporal. Nivel de Evidência III; Estudo de pacientes não consecutivos; sem padrão de referência "ouro" aplicado uniformemente.

Descritores: Futebol; Contagem de células sanguíneas; Ferro; Anemia.

\section{RESUMEN}

Introducción: Los atletas de fútbol pueden presentar alteraciones hematológicas que pueden comprometer su estado de salud. Además, la composición corporal inadecuada puede perjudicar el respectivo rendimiento. Objetivo: Evaluar la composición corporal y las alteraciones hematológicas a lo largo de un año en atletas de fútbol. Métodos: Se realizó un estudio observacional retrospectivo. Fueron colectados de los prontuarios de los atletas datos referentes a la edad, peso, estatura, composición corporal, hemograma, hierro sérico, ferritina sérica, transferrina sérica y capacidad total de unión del hierro en los meses de enero, mayo y agosto de 2015 y enero de 2016. El índice de masa corporal también fue calculado. Para los análisis estadísticos fueron utilizados el test Anova y el test post-hoc Tukey para las variables cuantitativas y el test de Qui-cuadrado para las variables cualitativas. El nivel de significancia adoptado fue de $p<0,05$. Resultados: Fueron evaluados los datos de 51 atletas, con un promedio de edad de 23,53 $\pm 3,11$ años, $77,10 \pm 6,56 \mathrm{~kg}, 1,80 \pm 0,07 \mathrm{~m}$ y 15,6 $22,89 \%$ de grasa corporal (GC). Se observó alteración significativa ( $p<0,05)$ del 
volumen corpuscular promedio, de la hemoglobina corpuscular promedio, de la concentración de hemoglobina corpuscular promedio, del tamaño celular y de los eosinófilos durante el período evaluado. Entre los atletas, 21,6\% presentaron hematocrito disminuido y 3,9\% presentaron hemoglobina por debajo de los valores de referencia. El \% de GC superior a 16\% se correlacionó significativamente con la depleción de hierro sérico $(p=0,01)$. Conclusión: Se observaron pequeñas alteraciones hematológicas significativas durante el año de competición deportiva, pero sin cambios significativos sobre la composición corporal. Nivel de Evidencia III; Estudio de pacientes no consecutivos; sin estándar de referencia "oro" aplicado uniformemente.

Descriptores: Fútbol; Recuento de células sanguíneas; Hierro; Anemia.

\section{INTRODUCTION}

Soccer, because of its specific condition, involves a large group of athletes. In addition, due to its popularity, biological scientists are showing increasing interest in studies delving deeper into a wide range of areas of knowledge related to this activity. ${ }^{1,2}$

The high-performance sport requires constant improvement of skills involved in its intervening variables (morphological, physiological, psychological, biomechanical, cognitive, etc.). It is known that to succeed in soccer it is important to balance the physical, technical, tactical, psychological and nutritional components, because if one of these falls short of requirements, performance may deteriorate and impair the player's chances of a successful career. ${ }^{3,4}$ In particular, the measurement of hematological and biochemical data provides many answers about how training is being interpreted by the various systems, in addition to being related to the quality of players' diets.,

Another important aspect for the detection and promotion of talents is the body composition of the athletes, since high levels of body fat are associated with poor fitness levels and a drop in performance in most sports. $4,7,8$

Endurance training, like in soccer, may bring about a decrease in erythrocyte, hemoglobin, hematocrit, iron and ferritin concentration, and may lead to changes in the health status of athletes. ${ }^{9,10}$ Moreover, restrictive or nutritionally imbalanced diets are associated with depletion of body iron contents. ${ }^{11}$ Thus, an assessment of the biochemical parameters of athletes is essential to help determine the health status of these individuals, complementing the overall assessment of nutritional, physiological, clinical and psychological aspects. ${ }^{4,11}$

The monitoring of athletes' body composition and hematological parameters is necessary to ensure good performance and avoid potential undesirable changes, such as iron deficiency and anemia. Thus, the aim of this study was to assess body composition and hematological changes over a year in professional soccer players from a professional club in Curitiba, PR, Paraná.

\section{MATERIALS AND METHODS}

A retrospective observational study was carried out with soccer players from a Series A soccer club in the city of Curitiba, PR, from January 2015 to January 2016.

This project was approved by the Institutional Review Board of Universidade Positivo under consolidated opinion no. 1145312.

During the study period, 51 soccer players were in the professional category of the club under evaluation. All players had at least five years of professional experience. The club was invited to participate in the study and to convey data from the medical records of the professional players who were in the club during the aforementioned period, by means of an informed consent form.

The inclusion criteria for the study were male soccer players aged between 17 and 30 years.
Data on age, body weight and height were obtained from the players' medical records, and information regarding body composition was obtained by dual-energy X-ray absorptiometry (DEXA). The device used for the scan was a Hologic ${ }^{\circledR}$ QDR $^{\circledR}$ X-ray bone densitometer produced by Hologic, Inc., Bedford, MA 01730, USA. Lean mass and total fat mass were determined to the nearest gram.

The biochemical tests used in this study were based on the blood test reports found in the players'medical records from January 2015 to January 2016. The tests are performed regularly in the months of January, May and August. The tests analyzed in this study were complete blood count, serum iron, serum ferritin, serum transferrin and total iron binding capacity.

The biochemical tests were carried out after the 12-hour fasting period on a midweek day, regardless of the training undertaken. Blood samples were collected at the actual club by practical nurses from a clinical laboratory in the city. Blood samples were taken in the morning (between 7:30 and 8:30 am), and the biochemical determinations were performed at the aforementioned city laboratory, under the technical responsibility of the biochemists of this lab. National literature for the adult male population was used to determine the reference ranges for the tests obtained. ${ }^{12,13}$

Body Mass Index (BMI) was calculated at this point, employing the formula that uses the individual's weight $(\mathrm{kg})$ versus height $(\mathrm{m})$ squared ratio, and classified according to the Brazilian Ministry of Health. ${ }^{14}$

The results were described by simple frequency distribution, mean and standard deviation, and compiled in the Microsoft Exce ${ }^{\circledR}$ program. For the statistical analyses we used the Anova and Tukey's post-hoc tests for quantitative variables and the Chi-square test for qualitative variables, with the aid of the Paleontological Statistics program, version 2.16. The significance level adopted was $p<0.05$.

\section{RESULTS}

The characterization and nutritional status of the studied sample can be seen in Table 1. It was observed that $19.6 \%(n=10)$ of the athletes had a BMl above $24.9 \mathrm{~kg} / \mathrm{m}^{2}$ and $1.96 \%(\mathrm{n}=1)$ had a BMl above $30 \mathrm{~kg} / \mathrm{m}^{2}$ with minor variations between the months evaluated, while $49.01 \%(n=25)$ of the players had a body fat percentage (BF\%) above 15\%.

Table 1. Characterization of the sample and nutritional status of professional soccer players, Curitiba, PR, 2016.

\begin{tabular}{c|c}
\hline Variable & Characterization \\
\hline Sample number & 51 \\
\hline Gender & Male \\
\hline Age & $24.5 \pm 3.78$ \\
\hline Height $(\mathrm{m})$ & $1.80 \pm 0.07$ \\
\hline Weight $(\mathrm{kg})$ & $77.10 \pm 6.56$ \\
\hline BMl $\left(\mathrm{kg} / \mathrm{m}^{2}\right)$ & $23.96 \pm 1.71$ \\
\hline Body fat $(\%)$ & $15.60 \pm 2.89$ \\
\hline Lean mass $(\mathrm{kg})$ & $65.88 \pm 6.09$ \\
\hline Fat mass $(\mathrm{kg})$ & $12.35 \pm 3.38$ \\
\hline
\end{tabular}

The values represent the mean and the standard deviation of the characterization and nutritional status of professional soccer players between January 2015 and January 2016, Curitiba, PR, 2016. Caption: Body Mass Index (BMI). 
Figure 1 shows the changes in body weight, lean mass (kg), fat mass (kg) and BF\% of the soccer players. None of the body composition variables differed significantly in the period under evaluation ( $p>0.05$ ).

Table 2 shows the hematological parameters of professional soccer players. All the test results were within the reference range. When assessing the lab tests according to the different months, we observed significant statistical changes in the following parameters: mean corpuscular volume (MCV), mean corpuscular hemoglobin (MCH), mean corpuscular hemoglobin concentration (MCHC), red cell distribution width (RDW) and eosinophils ( $p<0.05$ ).

Figure 2 shows the percentage of soccer players with depletion of laboratory test results related to anemia and iron metabolism. This figure highlights the hematocrit as the main altered laboratory indicator.

We found no relationship between BMl and hemoglobin, hematocrit, $\mathrm{MCH}, \mathrm{MCHC}$, RDW, iron, ferritin, transferrin and TIBC ( $p>0.05)$. However, a $\mathrm{BF} \%$ of up to $15 \%$ was significantly correlated with adequate serum iron, while a BF\% above $16 \%$ was correlated with serum iron depletion $(p=0.01)$.

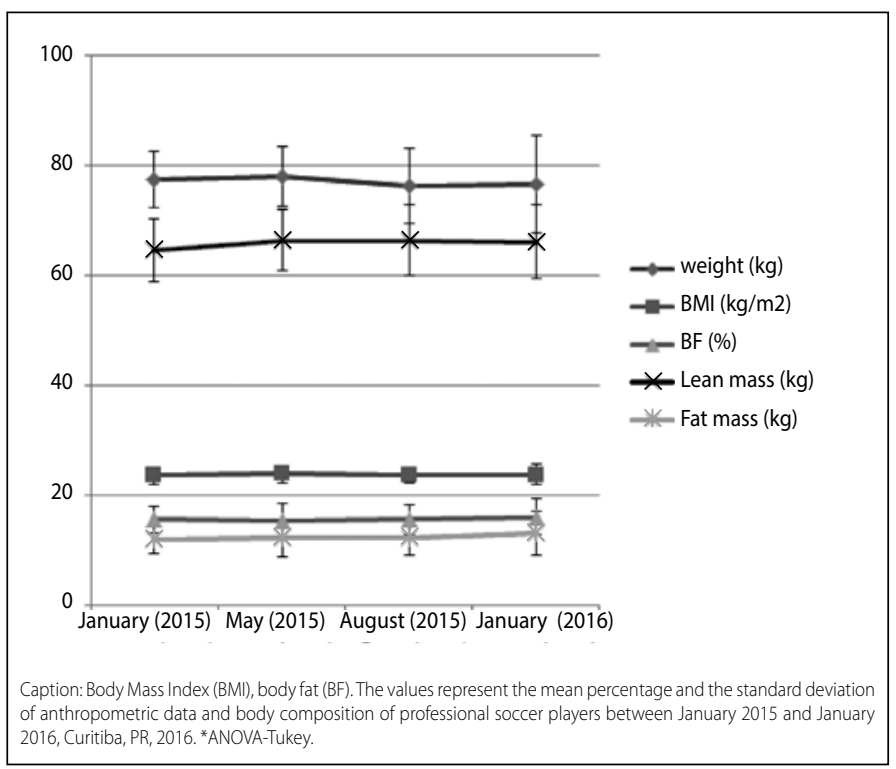

Figure 1. Anthropometric data and body composition of professional soccer players between January 2015 and January 2016, Curitiba, PR, 2016.

\section{DISCUSSION}

The annual mean BF\% of $15.60 \pm 2.89 \%$ found in this group of subjects corroborates other similar studies and verges on the recommended percentages established for these professional athletes, which range from 6 to $15 \%$, for optimum performance in this sport. ${ }^{15,16}$ It is important to keep in mind that the position of the players in the study was not evaluated, since different positions may have different levels of body fat, such as the goalkeeper, who may have a slightly higher body fat percentage than the others. ${ }^{16}$

It is necessary to monitor hematological parameters of athletes during competitive seasons to verify possible changes. The stability of these parameters is one of the main determinants of good performance, especially in endurance sports such as soccer. ${ }^{17,18}$

In this study, the blood count depicted values within the reference ranges. However, some of the parameters evaluated showed significant changes between the periods evaluated (Table 2). Iron values were

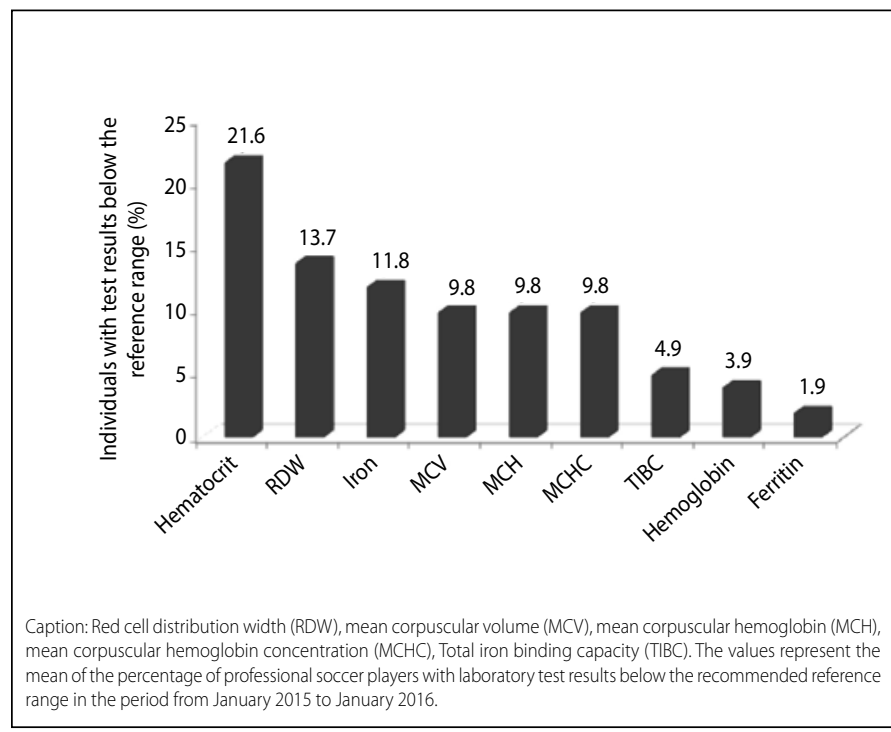

Figure 2. Percentage of professional soccer players with iron depletion in the laboratory test results related to anemia and iron metabolism in the period from January 2015 to January 2016, Curitiba, PR, 2016.

Table 2. Hematological parameters of soccer players between January 2015 and January 2016, Curitiba, PR, 2016.

\begin{tabular}{|c|c|c|c|c|c|c|}
\hline Test & Ref. Range & \begin{tabular}{|c|} 
Time 1 \\
January/2015 $(n=15)$ \\
\end{tabular} & $\begin{array}{c}\text { Time } 2 \\
\text { May/2015 }(n=27) \\
\end{array}$ & $\begin{array}{c}\text { Time } 3 \\
\text { August/2015 }(n=28)\end{array}$ & $\begin{array}{c}\text { Time } 4 \\
\text { January/2016 }(n=28)\end{array}$ & $\mathrm{p}$-value \\
\hline Erythrocytes & $4.5-5.9 \mathrm{~mm}^{3}$ & $5.49 \pm 0.46$ & $5.43 \pm 0.39$ & $5.58 \pm 0.37$ & $5.55 \pm 0.41$ & 0.52 \\
\hline Hemoglobin & $14-18 \mathrm{~g} / \mathrm{dL}$ & $16.13 \pm 0.84$ & $15.5 \pm 0.91$ & $16.05 \pm 0.93$ & $15.53 \pm 0.84$ & 0.81 \\
\hline Hematocrit & $45-52 \%$ & $47.35 \pm 2.53$ & $46.7 \pm 1.95$ & $47.13 \pm 2.23$ & $46.56 \pm 2.35$ & 0.63 \\
\hline MCV & 80-100 fL & $87.11 \pm 2.42^{\mathrm{a}}$ & $86.62 \pm 4.3^{a}$ & $84.67 \pm 3.97^{\mathrm{a}}$ & $83.8 \pm 4.91^{b}$ & 0.02 \\
\hline $\mathrm{MCH}$ & $26-32 \mathrm{pg}$ & $29.72 \pm 1.07^{\mathrm{a}}$ & $28.63 \pm 1.95^{\mathrm{a}}$ & $28.86 \pm 1.69^{\mathrm{a}}$ & $28.05 \pm 2.05^{b}$ & 0.03 \\
\hline $\mathrm{MCHC}$ & $32-36 \%$ & $34.12 \pm 0.56^{a}$ & $33.06 \pm 1.1^{b}$ & $34.04 \pm 0.87^{\mathrm{a}}$ & $33.4 \pm 1.05^{a . b}$ & $<0.001$ \\
\hline RDW & $11.5-15.5 \%$ & $11.79 \pm 0.43^{\mathrm{a}}$ & $12.0 \pm 0.5^{a . b}$ & $11.94 \pm 0.39^{a . b}$ & $12.24 \pm 0.67^{b}$ & 0.03 \\
\hline Leucocytes & $4,000-11,000$ & $6120.67 \pm 983$ & $6033 \pm 1214$ & $5528.9 \pm 1659$ & $5656.07 \pm 1384$ & 0.16 \\
\hline Eosinophils & $0-5 \%$ & $1.67 \pm 1.54^{\mathrm{a}}$ & $2.18 \pm 1.4^{a . b}$ & $2.46 \pm 1.64^{a . b}$ & $3.25 \pm 2.24^{b}$ & 0.02 \\
\hline Rods & $0-5 \%$ & $1.67 \pm 1.84$ & $1.54 \pm 0.88$ & $0.93 \pm 1.18$ & $1.33 \pm 0.62$ & 0.12 \\
\hline Platelets & $150,000-450,000$ & $238400 \pm 57430$ & $233596 \pm 63657$ & $2312000 \pm 70839$ & $220214 \pm 40142$ & 0.19 \\
\hline Iron & $80-180 \mu \mathrm{g} / \mathrm{dL}$ & $123.30 \pm 32.0$ & $112.3 \pm 25.4$ & $109.85 \pm 36.83$ & $105.00 \pm 27.67$ & 0.30 \\
\hline Ferritin & $12-300 \mu \mathrm{g} / \mathrm{dL}$ & $139.45 \pm 58.8$ & $124.4 \pm 94.6$ & $100.96 \pm 51.05$ & $138.25 \pm 94.6$ & 0.28 \\
\hline Total iron binding capacity & $250-420 \mu \mathrm{g} / \mathrm{dL}$ & $344.07 \pm 42.46$ & * & $327.36 \pm 75.60$ & $356.25 \pm 41.07$ & 0.26 \\
\hline Transferrin & $212-360 \mathrm{mg} / \mathrm{dL}$ & $249.87 \pm 35.86$ & $*$ & $247.27 \pm 32.48$ & $245.86 \pm 31.2$ & 0.92 \\
\hline
\end{tabular}


lower than the reference range in $11.8 \%$ of the players analyzed, and the mean iron concentration decreased over the course of the year evaluated. Low levels of iron in elite athletes may occur due to hemolysis, gastrointestinal bleeding, hematuria, sweating, low iron intake and/or intestinal malabsorption. In addition, differences in consecutive blood tests may occur as a result of changes in intensity and type of training or competition, and vary during the competitive year as a consequence of different training methods. ${ }^{17,18}$ Hematological variables are normally higher at the start of the competition season, gradually declining as athletes undergo greater physical strain. ${ }^{18}$ This trend was observed in $\mathrm{MCV}$ and serum iron values in this study.

Iron depletion influences MCV values, since this test evaluates the size of red blood cells and helps to diagnose the type of anemia; however, it takes more than three months of deficiency for the cells to become microcytic and to alter the MCV. ${ }^{12}$

On the contrary, eosinophils had two sequential peaks, yet both were nonsignificant and within the reference range (Table 2 ). This result differs from that found by Silva et al. ${ }^{19}$ and Coswig, Neves and Del Vecchio, ${ }^{20}$ who mention that a smaller number of eosinophils is observed in athletes experiencing the effects of overtraining due to the overload that triggers injuries and inflammation.

Ferritin and TIBC levels dropped during the competitive year, yet after the Christmas holidays values were back at the levels recorded in the same prior-year period. (Table 2) After calculating the annual mean serum ferritin, a state of depletion of this marker was observed in only $1.96 \%(n=1)$ of the players, which may be related to the training load, because as the load increases, there is a tendency for levels of ferritin, which is considered a marker of training tolerance in endurance athletes and is related to gradual depletion of iron stores, to drop. ${ }^{21}$

Among the players assessed in this study, 4.9\% had high TIBC values in comparison to the reference range, which may be associated with the iron depletion that occurred in some of the athletes, since when there is a drop in iron and transferrin saturation levels, the TIBC values increase. ${ }^{21}$

An important result was found in this study in which BF\% above 16\% was correlated with iron depletion ( $p=0.01$ ). This result can be explained by the need to decrease the body fat percentage and the implementation of a restrictive and inadequate diet, which, together with strenuous training and competitions, contribute to nutrient deficiency.

However, a potential limitation of this study is the absence of a food consumption analysis, a factor that could be useful in the seasonal analysis of laboratory tests, especially of iron. In addition, there is the question of whether these findings in professional soccer players are due to the specific training load or even the exercise volume.

\section{CONCLUSION}

In this study we observed a small increase in the BF\% of part of the group of professional soccer players with few significant hematological changes during the competitive year. There was no association between $\mathrm{BMI}$ or low BF\% and the biochemical parameters evaluated. However, above-average BF\% was correlated with iron depletion. Further studies should be conducted to explore this finding.

All authors declare no potential conflict of interest related to this article.

AUTHORS' CONTRIBUTIONS: Each author made significant individual contributions to this manuscript. AKB (0000-0003-4974-7677)* and BNF (0000-0003-0132-1298)*: data analysis and writing; RMF (0000-0002-2368-1641)*: analysis, data interpretation and writing; GSL (0000-0001-6296-3206)*: collection, analysis and interpretation of results; PDB (0000-0002-8274-0023)*: supervision, conception and design of the study; TRM (0000-0002-0884-8052)*: supervision, collection, analysis and interpretation of data. All authors contributed to the intellectual concept of the study and approved the final version of the manuscript. *ORCID (Open Researcher and Contributor ID).

\section{REFERENCES}

1. Prado WL, Botero JP, Guerra, RL, Rodrigues CL, Cuvello LC, Dâmaso AR. Perfil antropométrico e ingestão de macronutrientes em atletas profissionais brasileiros de futebol, de acordo com suas posiçōes. Rev Bras Med Esporte. 2006;12(2):61-5.

2. Lima $C B$, Martins $M E$, Liberali R, Navarro, F. Estado nutricional e composição corporal de jogadores de futebol profissional. RBNE. 2009;3(18):562-9.

3. Mantovani TV, Rodrigues GA, Miranda JM, Palmeira MV, Abad CC, Wichi RB. Composição corporal e limiar anaeróbio de jogadores de futebol das categorias de base. Revista Mackenzie de Educação Física e Esporte. 2008;7(1):25-33.

4. Gorla JI, Silva, AA, Campos LF, Santos CF, Almeida JJ, Duarte E, et al. Composição corporal e perfil somatotípico de atletas da seleção brasileira de futebol de 5. Rev Bras Ciênc Esporte. 2017;39(1):79-84.

5. Cordeiro EM, Gomes AL, Guimarães M, Silva SG, Dantas EH. Alterações hematológicas e bioquímicas oriundas do treinamento de combate em atletas de Kung fu olímpico. Fit Perf J. 2008;6(4):255-61.

6. Monteiro AN, Bassini A, Cameron LC. Perfil hematológico e de reservas de macronutrientes em jogadores de futebol em fase pré-temporada. Fit Perf J. 2006;5(3):129-33.

7. Keogh J. The use of physical fitness scores and anthropometric data to predict selection in an elite under 18 Australian rules football team. J Sci Med Sport. 1999;2(2):125-33

8. ReyllyT, Bangsbo J, Franks A. Anthropometric and physiological predispositions for elite soccer. J Sports Sci. 2000;18(9):669-83.

9. Schumacher YO, Schmid A, Grathwohl D, Bültermann D, Berg A. Hematological indices and iron status in athletes of various sports and performances. Med Sci Sports Exerc. 2002;34(5):869-75.

10. Lukaski HC. Vitamin and mineral status: effects on physical performance. Nutrition. 2004;20(7-8):632-44.

11. Carvalho CM. Avaliação nutricional, composição corpórea e avaliação bioquímica de atletas de futebol de categorias de base na pré-temporada e meio da temporada. Dissertação (Mestrado)
Curso de Saúde da Criança e do Adolescente, Setor de Ciências da Saúde, UFPR, Curitiba, 2014. $135 f$.

12. Koury JC, Buss C. Indicadores bioquímicos para avaliação de atletas. In: Biesek S, Alves LA, Guerra I, org. Estratégias de nutrição e suplementação no esporte. 3.ed., rev. atual. Barueri: Manole, 2015. p. 169-174.

13. Ravel R. Laboratório clínico: aplicações clínicas dos dados laboratoriais. 6.ed. Rio de Janeiro: Guanabara Koogan, 2009

14. Brasil. Ministério da Saúde. Orientações para coleta e análise de dados antropométricos em serviços de saúde: Norma Técnica do Sistema de Vigilância Alimentar e Nutricional. Brasília: SISVAN: Ministério da Saúde, 2011.

15. Preteça DR. Comparação dos métodos de bioimpedância "hand to hand" e equação de Faulkner para avaliação da composição corporal em jogadores de futebol brasileiro. Rev Digital. 2009;13(130).

16. Gerosa-Neto J, Rossi FE, Silva CB, Campos EZ, Fernandes RA, Freitas Júnior IF. Body composition analysis of athletes from the elite of brazilian soccer players. Motricidade. 2014;10(4):105-10.

17. Banfi G, Del Fabbro M, Mauri C, Corsi MM, Melegati G. Haematological parameters in elite rugby players during a competitive season. Clin Lab Haematol. 2006;28(3):183-8.

18. Ostojic SM, Ahmetovic, Z. Indicators of iron status in elite soccer players during the sports season. Int J Lab Hematol. 2009;31(4):447-52.

19. Silva AS, Papoti M, Pauli JR, Gobatto, CA. Elaboração de tabelas de percentis através de parâmetros antropométricos, de desempenho, bioquímicos, hematológicos, hormonais e psicológicos em futebolistas profissionais. Rev Bras Med Esporte. 2012;18(3):148-52.

20. Coswig VS, Neves AH, Del Vecchio FB. Efeitos do tempo de prática nos parâmetros bioquímicos, hormonais e hematológicos de praticantes de jiu-jitsu brasileiro. Rev Andal Med Desporte. 2013;6(1):17-23.

21. Grotto HZ. Diagnóstico laboratorial da deficiência de ferro. Rev Bras Hematol Hemoter. 2010;32(suppl. 2):22-8. 